\title{
CHARACTERISTIC OF SEDIMENT AT LEKOK COASTAL WATERS, PASURUAN REGENCY, EAST JAVA
}

\section{KARAKTERISTIK SEDIMEN DI PERAIRAN PESISIR LEKOK, KABUPATEN PASURUAN, JAWA TIMUR}

\author{
Rifka Rimbi Anggraini ${ }^{*}$, Uun Yanuhar $^{2}$, \& Yenny Risjani ${ }^{2}$ \\ ${ }^{1}$ Master Program of Aquaculture, FPIK-UB, Malang, 65145, Indonesia \\ ${ }^{2}$ Department of Aquatic Resources Management, FPIK-UB, Malang, 65145, Indonesia \\ *E-mail: rifkarimbi@gmail.com
}

\begin{abstract}
Sedimentation is one of the dynamics that occur in coastal areas to determine the condition of the coast. Lekok coastal water is one of the open water areas that have very fluctuating dynamics in coastal changes. The structural study of sediment distribution conducted in this location is used to provide information about the process of transportation and sedimentation based on the distribution of sediment grain size. This study aims to determine the horizontal grain sediment size in the Lekok coastal waters. This research was conducted at nine sampling points by sampling in the form of primary sediments randomly using the grab sampler method. Furthermore, further analysis is done by the gravimetric method. Based on the results of the study note that sediments characteristic in Lekok coastal water are generally dominated by three types of sediments, namely: sandy loam, loam, and silt loam. Sorting values are in a well-sorted to the moderately well-sorted condition where the sediment conditions are well sorted. The skewness value is skewed positively, where the value indicates a positive skewed sedimentary condition. The value of kurtosis is in the leptokurtic condition where the sediment from station 1 to station 9 is homogeneous.
\end{abstract}

Keywords: Lekok coastal waters, kurtosis, sediment, skewness, sorting

\section{ABSTRAK}

Sedimentasi merupakan salah satu dinamika yang terjadi di kawasan pesisir untuk mengetahui kondisi pantai tersebut. Perairan pesisir Lekok merupakan salah satu kawasan perairan terbuka yang memiliki dinamika perubahan pesisir sangat fluktuatif. Studi sebaran jenis sedimen yang dilakukan secara terstruktur pada lokasi ini digunakan untuk memberikan informasi mengenai proses transportasi dan pengendapan sedimen berdasarkan distribusi ukuran butir sedimen. Penelitian ini bertujuan untuk mengetahui ukuran butir sedimen secara horizontal di perairan pesisir Lekok. Penelitian ini dilakukan pada sembilan titik sampling dengan pengambilan sampel berupa sedimen dasar secara acak dengan menggunakan metode grab sampler. Selanjutnya dilakukan analisis lebih lanjut dengan metode gravimetri. Berdasarkan hasil penelitian diketahui bahwa karakteristik sedimen dalam perairan pesisir Lekok umumnya didominasi oleh tiga jenis sedimen yaitu: lempung berpasir, lempung dan lempung lanau. Nilai sorting berada dalam kondisi well-sorted hingga kondisi moderately well-sorted di mana kondisi sedimen didominasi dengan well sorted. Nilai skewness berada pada nilai skewed positively dimana nilai menunjukkan hasil positif. Nilai kurtosis berada pada leptokurtic dimana sedimen dari stasiun 1 ke stasiun 9 homogen.

Kata kunci: sedimen, kurtosis, perairan pesisir Lekok, skewness, sorting

\section{INTRODUCTION}

Muara is an area of land and seawater where the sedimentation of fine mud as a result of interactions that occur in waters, such as currents, tides, and salinity. This causes the estuary to function as an area with the limited exchange that can act as a 
discharge or source of sediment, and sediments associated with contaminants are discharged into the aquatic environment (Rainey et al., 2003). One of the goals of sedimentology is to interpret the environmental conditions of the grain size distribution found in sediment deposits (McLaren \& Bowles, 1985). Characteristics regarding the texture of sediments, especially in estuaries, are essential in classifying various micro-depositional environments (Ganesh et al., 2013). Sediment deposition is assumed through the distribution of sediment grain size (Nugroho \& Basit, 2014). The essential sedimentary characteristics are particle size and sediment grain, porosity, shape, and sediment fall velocity (Bayhaqi \& Dungga, 2015).

The fundamental aspect of sediment particles in influencing the processes of sedimentation, transportation, and sedimentation is grain size (Blott \& Kenneth, 2001). Grain size analysis provides information on sediment origin, transportation history, and depositional conditions (Folk \& Ward, 1957; Friedman, 1979; Bui et al., 1990). The distance from the coastline strongly influences the grain size distribution, the distance from the source (river), source of sediment material, topography, and sediment transport mechanism (Abuodha, 2003). Gravimetric analysis is the analysis of sediment grain size (Wibowo, 2011). This analysis is used to determine the level of resistance to the exogenic processes of sediment grains, such as weathering, erosion, and abrasion from the origin of transportation and sediment deposition processes (Yasin et al., 2016).

Sediments in coastal areas are more dynamic to experience erosion, transportation, and sedimentation on spatial and temporal scales. It is imperative to know the prediction of coastal evolution in the future (Winter, 2007). In addition, currents, which are oceanographic factors, can help the process of sediment distribution, especially suspended sediment (Purnawan et al., 2012).
The distribution of sediment fractions is strongly influenced by currents (Darlan, 1996), and the distribution mechanism is highly dependent on hydraulic sorting and deposition (Wenno \& Witasari, 2001).

Lekok coastal waters have an important role for the community in Pasuruan Regency. This condition occurs because of the dependence of the community in the economic field, where most of the population in this region lives as a fisherman (Hambali \& Aprianti, 2016). These waters are very active, which can be seen from the many settlements, industrial activities, agriculture to the activities of fishers (Haryono et al., 2017). However, this can hurt the activities of the fishermen due to sedimentation at the port, which results in severe silting (Hambali \& Aprianti, 2016). One of the aggravating conditions where Lekok coastal waters is a coastal area that is very much influenced by the entry of land, especially the Rejoso River (Haryono et al., 2017). The activity has much influence on the condition of the Lekok coastal waters. One of affecting sedimentation is mangrove's any vegetation was cut down, and the land was used as residential and industrial purposes (Aritonang et al., 2014).

It will significantly affect the sedimentation process in Lekok coastal waters. This sedimentation process occurs because of the widespread sediment deposition on land, on the coast and at sea. Sediment characteristics such as grain size, grain shape, and texture of sediment will differ from one place to another. The characteristics of the sediment depend on the type, characteristics, and location of the sediment (Dewi \& Yudi, 2008). It is consistent with what was stated by Folk \& Sanders (1978) that the distribution of sediment grains is more dominantly influenced by the type and condition of the material source of the sediment, as well as the processes that occur in the material. However, previously, according to Ponce (1989), it was mentioned that sediment is one 
of the results of disintegration and decomposition of rocks where this process involves changing rocks into smaller grains without destroying the chemical substance of the rock itself.

It is necessary to do a proper sediment analysis to find out the grain size, grain shape to the texture of the sediment in the water. Sediment grain size analysis is also widely used to determine the dynamics and depositional conditions in water (Stewart, 1958; Passega, 1964; CarranzaEdwards et al., 2005; Opreanu \& Păun, 2007). One alternative to assess the characteristics of the bottom water of sediments, it is necessary to determine statistical parameters such as mean grain size, skewness, and kurtosis (Dyer, 1986; CHL, 2002). In this article, the focus of the discussion is to describe the characteristics of horizontal sediment distribution based on the results of gravimetric analysis, sediment statistics, and spatially described to provide an overview of sediment sources, transportation processes and sediment deposition on the Lekok coastal waters.

\section{RESEARCH METHODS}

This research has been conducted in October-November 2019. The method used to collect the data in this study refers to a purposive sampling technique where the determination of the location points represent how many watersheds in the Lekok coastal waters (Figure 1). Sampling is done at low tide (Dewi et al., 2015). This research is a descriptive exploratory study in which this study describes a condition in the form of descriptions and descriptions in a systematic, factual and accurate manner about the facts, traits and examines the relationship between the phenomena that investigated (Nasir, 1983).

\subsection{Sample Preparation}

Grain size is a characteristic of sediments that can be measured in real terms in which to obtain this data; a filter analysis of sediment samples is required using the

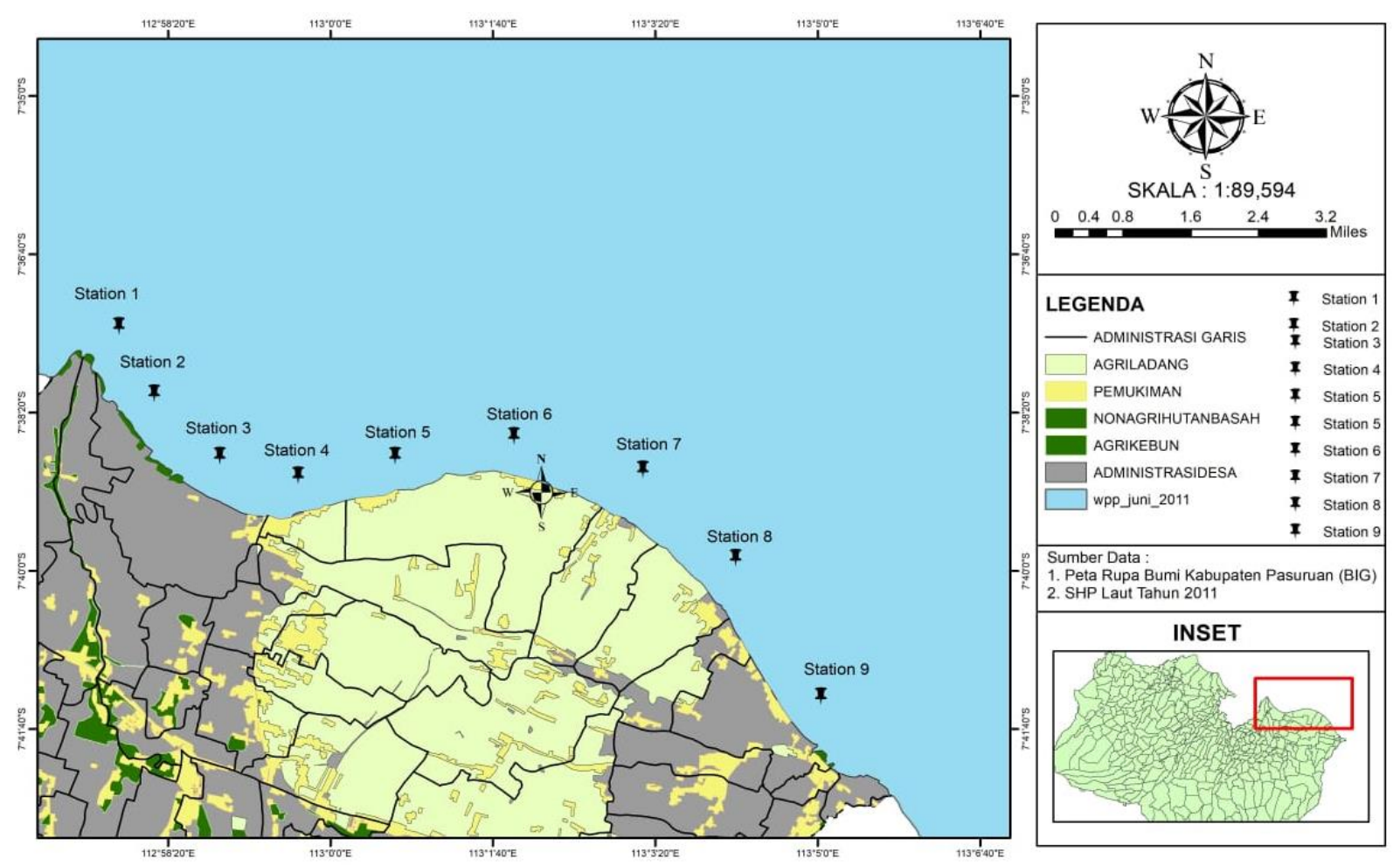

Figure 1. Map of Lekok Water research locations. 
U.S. standard classification. Army Corps Engineer (USACE) (Ghani et al., 2012). However, there are several other studies that use the wet sieving method with stratified sediment filters with different diameters. However, this research uses the method used by the Indonesian Institute of Sciences Oceanographic Research Center PK.001/GL/ 0611, written by Wibowo (2011). The work steps in the grain size analysis are based on the work procedures PK.001/GL/0611 P2O LIPI. The work steps are 100-gram sediment sample is put into an oven with a temperature of $80^{\circ} \mathrm{C}$ within 24 hours. Then prepare nine bowls that named after each cup in sequence according to the size of the multilevel sieve. Prepare multilevel sieves with each size of $16 \mathrm{~mm} ; 8 \mathrm{~mm} ; 4 \mathrm{~mm} ; 2 \mathrm{~mm} ; 1 \mathrm{~mm} ; 0.5 \mathrm{~mm}$; $0.25 \mathrm{~mm} ; 0.125 \mathrm{~mm}$ and $0.063 \mathrm{~mm}$.

\subsection{Collecting of Sample}

Sediment samples were collected from nine stations (Table 1) with three replications in Lekok coastal water. Sediment sampling used Ekman grab. Wet sediment samples were taken $300 \mathrm{~g}$ for analysis of sediment characteristics. Sediment samples that have been obtained then placed in a sealed bag and coated by aluminum foil (Dewi et al., 2015). Sediment samples are stored in ice-cooled boxes at $<4^{\circ} \mathrm{C}$ to maintain the sample conditions from the sampling location to the laboratory. After that, the sample is stored in a freezer with a temperature of $-20^{\circ} \mathrm{C}$ in the laboratory until further sediment analysis (Cordova \& Wahyudi, 2016).

After drying, the sediment sample is dissolved with water until it dissolves evenly in a stratified sieve then the sample is poured into a stratified sieve and doused with water. Place the filtered sediment at each level in a cup that has weighed that from the initial weight. When it is finished to the 9th level, the sample is dried at the same temperature as before. Look at the bottom of the filter container, and the remaining water is poured into a measuring cup as much as $2000 \mathrm{ml}$, then stirred a few minutes then allowed to stand for 31 minutes so that the silt particles will settle. After settling, water is removed and leave the sediment. Then the sediment is transferred to a weighted cup. They are that contains the sieving sediment from each sieve size is heated in an oven at a temperature of $80^{\circ} \mathrm{C}$ for 24 hours or until it is dry. Then the cup is allowed to stand at room temperature for 30 minutes. After that, this cup is weighed with analytical scales. Then do Shepard's triangle analysis (Shepard, 1954).

Table 1. Research location coordinate point.

\begin{tabular}{|c|c|c|}
\hline Stations & Latitude & Longitude \\
\hline 1 & $7^{\circ} 37^{\prime} 25^{\prime \prime} \mathrm{S}$ & $112^{\circ} 57^{\prime} 50^{\prime \prime} \mathrm{E}$ \\
\hline 2 & $7^{\circ} 38^{\prime} 08^{\prime \prime} \mathrm{S}$ & $112^{\circ} 58^{\prime} 12^{\prime \prime} \mathrm{E}$ \\
\hline 3 & $7^{\circ} 38^{\prime} 47^{\prime \prime} \mathrm{S}$ & $112^{\circ} 58^{\prime} 52^{\prime \prime} \mathrm{E}$ \\
\hline 4 & $7^{\circ} 38^{\prime} 60^{\prime \prime} \mathrm{S}$ & $112^{\circ} 59^{\prime} 40^{\prime \prime} \mathrm{E}$ \\
\hline 5 & $7^{\circ} 38^{\prime} 47^{\prime \prime} \mathrm{S}$ & $113^{\circ} 06^{\prime} 38^{\prime \prime} \mathrm{E}$ \\
\hline 6 & $7^{\circ} 38^{\prime} 35^{\prime \prime} \mathrm{S}$ & $113^{\circ} 01^{\prime} 53^{\prime \prime} \mathrm{E}$ \\
\hline 7 & $7^{\circ} 38,56 " \mathrm{~S}$ & $113^{\circ} 03^{\prime} 13^{\prime \prime} \mathrm{E}$ \\
\hline 8 & $7^{\circ} 39^{\prime} 52^{\prime \prime} \mathrm{S}$ & $113^{\circ} 41^{\prime} 36^{\prime \prime} \mathrm{E}$ \\
\hline 9 & $7^{\circ} 41$ ' 19 " $\mathrm{S}$ & $113^{\circ} 05^{\prime} 02^{\prime \prime} \mathrm{E}$ \\
\hline
\end{tabular}

\subsection{Analysis of Shepard Triangle}

Shepard triangle analysis is performed to see the type of sediment fraction that divided into three types, namely: sand, silt, and clay, that are obtained from the dry weight data of the sample. Determination of the type of sediment fraction is based on the most significant composition value from the data and also from work procedure PK.001/GL/0611 P2O LIPI (Wibowo, 2011). There are three sides in the Shepard triangle diagram, namely: sand, silt, and clay, which on each side has a percentage value of the fraction type. This result will be closed to $100 \%$ if the fraction type increasingly leads to the existing fraction type.

\subsection{Analysis of Data}

The grain size data is calculated using the calculation method that refers to PK.001/GL/0611 P2O LIPI (Wibowo, 2011): 
Early Sediment Weight $\left(\mathrm{W}_{\mathrm{s}}\right)$

$=\left(\mathrm{W}_{\mathrm{cw}+\mathrm{s}}\right)-\left(\mathrm{W}_{\mathrm{cw}}\right)$

$\%$ Sediment Grain Size

$=\frac{W c w+b(1-n)}{W s} \times 100 \%$

Information: $\mathrm{W}_{\mathrm{s}}=$ Sample Weight $(\mathrm{g}) ; \mathrm{W}_{\mathrm{cw}}=$ Weight of the Cup before filling the sample $(\mathrm{g})$; $\mathrm{W}_{\mathrm{cw}+\mathrm{s}}$ : Weight of the cup after filling the sample $(\mathrm{g}) ; \mathrm{W}_{\mathrm{cw}}+\mathrm{b}(1-\mathrm{n})$ : Weight of the cup containing the sifting sample from each size (g).

\subsubsection{Sorting}

Folk \& Ward (1957) states that sorting is used to see the uniformity of the grain size of a sediment population. Sorting is also interpreted as the spread of grain size over average grain size. Calculations for sorting values can be calculated with the following equation:

$$
I=\frac{\varphi 84-\varphi 16}{4}+\frac{\varphi 95-\varphi 5}{6.6}
$$

\subsubsection{Skewness}

Folk \& Ward (1957) states that skewness is one of the parameters in the calculation of sediment distribution which is widely used to determine the deviation of grain size distribution to normal distribution. If the grain size distribution of coarse particles is dominant, then the skewness value is negative, and this also applies to the reverse. Calculations for skewness values can be calculated with the following equation:

$\alpha \varphi=\frac{\varphi 16+\varphi 84-2 \cdot \varphi 50}{2(\varphi 84-\varphi 16)}+\frac{\varphi 5+\varphi 95-2 \cdot \varphi 50}{2(\varphi 95-\varphi 5)}$

\subsubsection{Kurtosis}

This kurtosis value is a factor for assessing flatness and peak of the sediment distribution against the normal distribution. Based on Folk \& Ward (1957), calculations for kurtosis values can be calculated with the following equation:
$K=\frac{\varphi 95-\varphi 5}{2.44(\varphi 75-\varphi 25)}$

Information: $\Phi 16=$ particle size $16 \%$; $\Phi 50=$ particle size $50 \%$; $\Phi 84=$ particle size $84 \%$; $\Phi 5=$ particle size $5 \%$; $\Phi 95=$ particle size $95 \%$; $\Phi 75=$ particle size $75 \%$; $\Phi 25=$ particle size $25 \%$.

\section{RESULTS AND DISCUSSION}

\subsection{The Characteristic of Bottom Sediment in Lekok coastal waters}

The grain size data obtained is based on the number of samples used, which are nine samples taken from the Lekok coastal waters. Samples that have been analyzed by the gravimetric method to determine the grain size of the sediment illustrate the variation in value and percentage of sediment grain size. The results obtained can be interpreted and given naming through the Shepard Triangle Diagram (Shepard, 1954) (Figure 2), thus providing convenience in interpreting and grouping types of sediments. In general, sediments found at the study site are dominated by sandy loam size (Figure 2; Figure 3).

Based on the results of the sifting and piping process, it is known that the percentage of the most considerable sedimentary content is sand, which is then followed by silt and clay. These results can be seen in Figure 2. The analysis of grain size shows that in Lekok coastal waters, water has three basic types of sediments, namely sandy loam, loam, and silt loam. Sandy loam types dominate basic sediment types in Lekok coastal waters. The primary sediment classification of Lekok coastal waters can be seen in Figure 3. The classification of sediments is due to the presence of sediments with more massive mass so that it will settle faster. Therefore, more sand types are found around the Lekok coastal waters. For sediment fraction, which tends to be coarser, it will be deposited more 


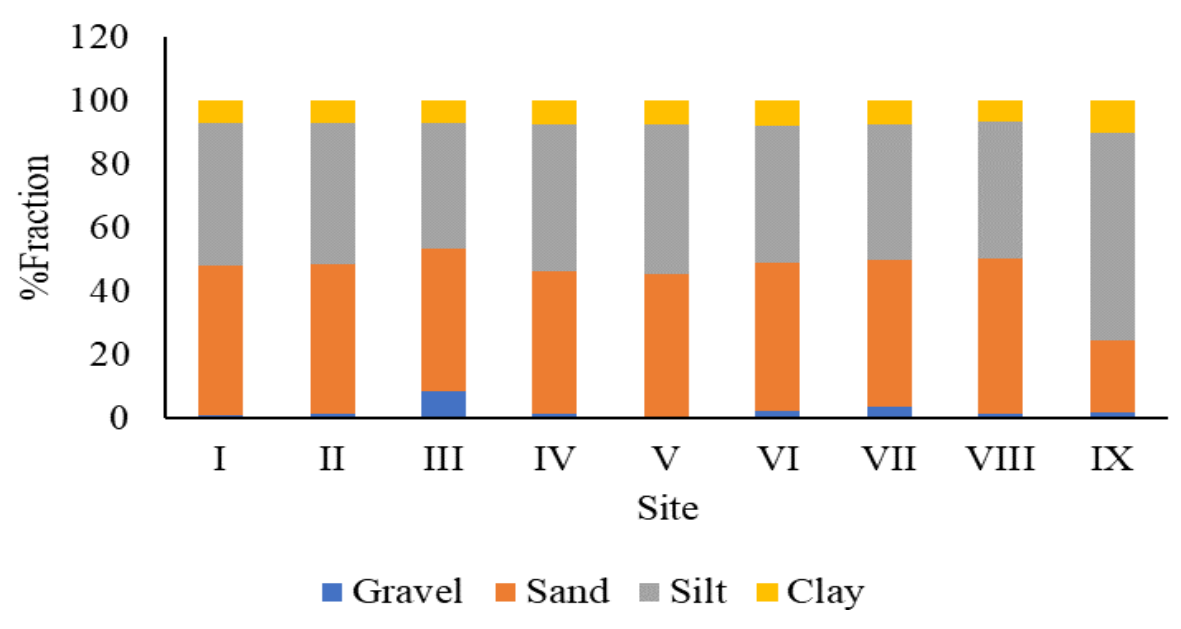

Figure 2. Characteristic of Lekok coastal waters sediment grain size.

quickly than finer sediment fraction. It is because these particles will be lowered by currents and deposited even further. Rifardi (2012) argues that a large sediment particle fraction will be deposited at a location not far from the source of the sediment. The sediment transport process is controlled by currents to be deposited if the finer particles of sediment in terms of grain size. The predominance of sediment in the form of sand is because the area is part of the sea waters adjacent to the main river estuary around the study site (Gemilang et al., 2018).

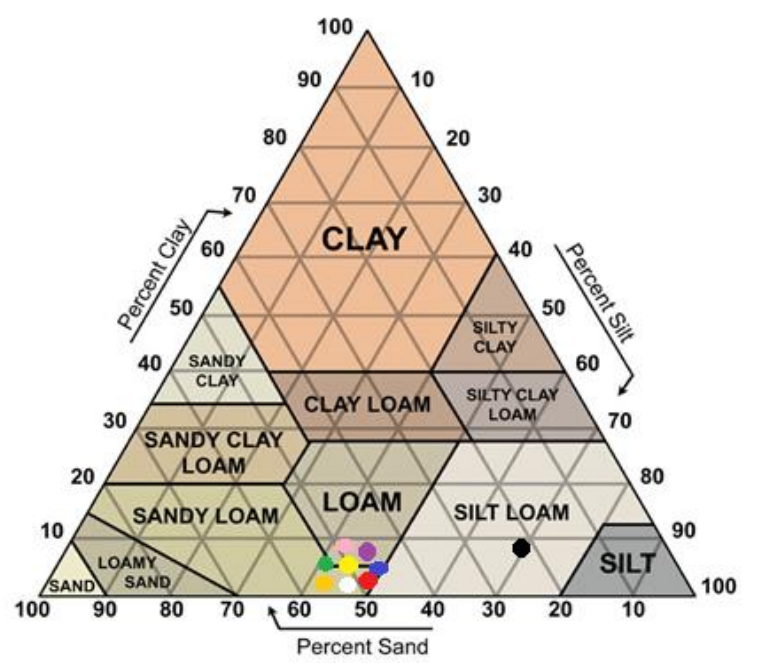

Figure 3. Classification of sediment.

The sediment fraction brought not only from one river but also from another river. Large discharges will tend to carry coarse and large sedimentary fractions and precipitate them. The position of the station away from the river or located in the river mouth can affect the flow velocity of the river flow and waves that have been weakened or not as strong as in the watershed so that they are only able to carry small and fine-sized fraction types. The types of silt and clay fractions have smaller mass and diameter compared to coarse and large finished fractions such as sand, gravel, and crust. It causes the faction to be carried away by the flow of water; the more towards the high seas, the new power will weaken (Ningsih et al., 2013).

Statement of Astrini et al. (2014) estuary base substrate types are generally in the form of mud (silt) and clay (clay). The substrate in the form of mud shows that in estuary areas have a high level of sedimentation. This sediment originates from the upstream area of the river, which carries eroded terrestrial material to the downstream so that there is considerable sedimentation in the river mouth. According to Affandi \& Surbakti (2012) because the energy of water motion in a river mouth is tremendous, so it carries granules in the form of suspension.

The difference in grain size is very closely related to the origin of the sediment source. This condition explains that the source of sediment originating from the sea 
then undergoes a transportation process that eventually undergoes a process of deposition into the sediment at each location. Also, the coarser grain size is assumed to be the result of the process of grinding the sand shoals (sand islands) by waves, which then transport at the front of the water bottom (Gemilang et $a l ., 2018)$. The difference in grain size in sediments is very closely related to the source of the sediment derived. If the source comes from the direction in the bay, the grain size of the sediment will be even smoother.

Meanwhile, if the sediment faces towards the high seas, the grain size produced is more coarse. This condition explains that the source of sediment comes from the sea, then it will undergo a process of transportation that will settle into the sediment at each location. Sediment composition also shows the type of sediment. In general, sediment deposits that are found near the beach in the form of fine-sized rocks and clay minerals and plant residues. These deposits are called thermogenic deposits. This condition characterizes that the sediment is influenced by volcanic and terrestrial activity (Nugroho \& Basit, 2014).

The process of refining the sediment grains while heading to the coast is caused by the influence of the periodicity of the monsoon in the Java Sea. The sediment sampling process that enters the transitional monsoon period will be characterized by a weak wind pattern and an uncertain direction (Siregar et al., 2017). Weak wind conditions can result in a tendency for grain size to become smoother when heading towards the coast. Davis (1991) also states that river currents entering sea waters will experience a slowdown where the ability to transport material will be reduced so that there will be a deposition process at the mouth of the estuary and the front of the river mouth. Tidal conditions can influence the tidal current velocity, which will be more varied and fluctuating so that there will be differences in the mechanism of transport and sediment deposition in each existing tidal condition (Hoekstra et al., 2002). It is following what was conveyed by Nugroho \& Basit (2014), where sediment transportation is also strongly influenced by current fluctuations so that it can sort various sizes of fine sediment.

\subsection{Statistical Interpretation of Sediment Grain Size}

Sediment distribution for sorting value at the observation location is in a wellsorted to the moderate sorted condition where the sediment conditions are well sorted with an indication that the speed of the current affects the high deposition. Skewness value at skewed observation location is skewed positively where the value indicates positively skewed sediment condition, which indicates that the observation location is on the fine-sized substrate but does not lead to mud. The kurtosis value at the study site is leptokurtic, where the value is known that the sediments from site 1 to site 9 are homogeneous. Data on sediment distribution in Lekok coastal waters are presented in Table 2.

The relationship between kurtosis, sorting, and skewness is widely used to determine the differences in sediment in each water. Human activity is a supporting factor for the process of sedimentation other than due to natural factors. The distribution of sediment can be known from where the source of sediment originates from skewness and sorting data. Sediment sorting value at the study site is included in Well Sorted. Based on the opinion of Ingmanson \& Wallace (1989), wherein his article, it was stated that sediments with good sorting value are caused by the size of the sediment particles which are well accumulated or structured. This condition is strongly influenced by the strength of currents and waves that tend to be stable. Briefly stated that the strength of each oceanographic parameters are similar so that sediment grains undergoing precipitation tend to be the same (Rifardi, 2012). 
Table 2. Distribution of sediment in Lekok coastal waters.

\begin{tabular}{clll}
\hline Site & \multicolumn{1}{c}{ Skewness } & \multicolumn{1}{c}{ Sorting } & \multicolumn{1}{c}{ Kurtosis } \\
\hline 1 & Fine Skewed & Well Sorted & Very Leptokurtic \\
2 & Symmetrical & Well Sorted & Leptokurtic \\
3 & Skewed Positively & Well Sorted Moderately & Very Leptokurtic \\
4 & Skewed Positively & Well Sorted Moderately & Leptokurtic \\
5 & Very Positively Skewed & Sorted & Leptokurtic \\
6 & Skewed & Well Sorted & Very Leptokurtic \\
7 & Skewed Positively & Well Sorted & Very Leptokurtic \\
8 & Fine Skewed & Well Sorted Moderately & Very Leptokurtic \\
9 & Skewed Positively & Well Sorted Moderately & Leptokurtic \\
\hline
\end{tabular}

Besides, the process of the meeting between river currents and ocean currents can cause gradations of current energy (Gemilang et al., 2018). This sorting value indicates the type of deposition, the characteristics of the settling current, and the settling time speed (Solahuddin et al., 2006). Scattered and deposited sediments at the study site showed that the sediments had a long time for the deposition process, which is indicated by the type of sorting that has an excellent uniformity of sediment grains.

The skewness value obtained in this study is dominated by skewed positively. It shows that the sediment has undergone a process of transportation and sedimentation in these waters. Skewness values obtained indicate differences in sediment texture between stations that illustrate the strength of energy that works in these waters are not dominantly the same or change (Arjenggi et al., 2013). Skewness condition at the study location indicated that the substrate at the study location tended to be of smooth size. Kurtosis value obtained is an illustration of the relationship of sorting the middle and bottom by showing the sediment criteria through graphs (Darlan, 1996). The process of forming sediments is one way to record long past events, especially those stored on the ocean floor.

Not only the history of the life of biota that lives in the sea, but this sedimentary rock will also record the history of volcanic eruptions, major floods, and climate change (Anderson, 1988).

\section{CONCLUSION}

The results of Lekok coastal waters sediment grain size analysis are dominated by three basic sediment types, namely sandy loam, loam, and silt loam. Sandy loam types dominate basic sediment types in Lekok water. Sediment distribution for sorting values is in a well-sorted to moderately wellsorted condition. Furthermore, the value of skewness is dominantly skewed positively. The kurtosis value at the study site is leptokurtic, where the value is known that the sediments from site 1 to site 9 are homogeneous. Skewness, kurtosis, and sorting data are data used to see the source of sediment originating.

\section{ACKNOWLEDGMENTS}

Our gratitude goes to Mr. Nur Habibie as a facilitator of the researcher for being able to research the Coastal Waters of Lekok, Pasuruan Regency. Furthermore, we also thank the Head of Soil Laboratory, Faculty of Agriculture, Brawijaya University, for facilitating researchers in this research.

\section{REFERENCES}

Abuodha, J.O.Z. 2003. Grain size distribution and composition of 
modern dune and beach sediments, Malindi Bay coast, Kenya. J. of African Earth Sciences, 36: 41-54. https://doi.org/10.1016/S08995362(03)00016-2

Affandi, A.K. \& H. Surbakti. 2012. Distribusi sedimen dasar di Perairan Pesisir Banyuasin Sumatera Selatan. J. Maspari, 4: 33-39. https://doi.org/10.36706/maspari. v4i1.1327

Anderson, R.N. 1988. Marine Geology. Lamont-doherty geological observation. Columbia University. Palisades: New York. 33 p.

Aritonang, A.E., H. Surbakti, \& A.I.S. Purwiyanto. 2014. Laju pendendapan sedimen di Pulau Anakan Muara Sungai Banyuasin, Sumatera Selatan. J. Maspari, 6(2): 133-141. https://doi.org/10.36706/maspari.v8i1 .2645

Arjenggi, E.K., Muzahar, \& Y. Falmi. 2013. Karakteristik sedimen permukaan dasar di Perairan Kelurahan Tarempa Barat Kecamatan Siantan Kabupaten Anambas. Jurusan Ilmu Kelautan. Universitas Maritim Raja Ali Haji. 19 pp. https://jurnal.umrah.ac.id/?p=3319

Astrini, A.D.R., Y. Muhammad, \& S. Adi. 2014. Kondisi perairan terhadap struktur komunitas makrozoobenthos di Muara Sungai Karanganyar Dantapak, Kecamatan Tugu, Semarang. J. of Marine Research, 3: 27-36. https://doi.org/10.14710/jmr.v3i1.459 4

Bayhaqi, A. \& C.M.A. Dungga. 2015. Distribusi butiran sedimen di pantai Dalegan, Gresik, Jawa Timur. Depik, 4(3): 153-159. https://doi.org/10.13170/depik.4.3.30 54

Blott, J.S. \& P. Kenneth. 2001. Gradistat: A grain size distribution and statistics package for analysis of unconsolidated sediments. Earth Surface Processes and Landforms: British Society for Geomorphology, 26: 1237-1248. https://doi.org/10.1002/esp.261

Bui, E.N., J.M. Mazullo, \& L.P. Wilding. 1990. Using quartz grain size and shape analysis to distinguish between Aeolian and fluvial deposits in the Dallol Bosso of Niger (West Africa). Earth Surface Process and Landforms, 14: 157-166. https://doi.org/10.1002/esp.32901402 06

Carranza-Edwards, A., L. Rosales-Hoz, J. Urrutia-Fucugauchi, A. SandovalFortanel, E.M. de la Garza, \& R.L.S. Cruz. 2005. Geochemical distribution pattern of sediments in an active continental shelf in Southern Mexico. Continental Shelf Research, 25: 521537.

https://doi.org/10.1016/j.csr.2004.09. 013

Coastal Hydraulic Laboratory (CHL). 2002. Coastal Engineering Manual Part III. Washington DC: Department of the Army. U.S. Army Corp of Engineers. III-3-48 pp. http://www.plainwater.com/pubs/EM1110-2-1100P3.pdf

Cordova, M.R. \& J.A. Wahyudi. 2016. Microplastic in the Deep-Sea Sediment of Southwestern Sumatera Waters. J. of Marine Research Indonesia, 41(1): 27-35. https://doi.org/10.14203/mri.v41i1.99

Darlan, Y. 1996. Geomorfologi wilayah pesisir. Aplikasi untuk penelitian wilayah pantai. Pusat Pengembangan Geologi Kelautan. Bandung. 96 p.

Davis, Jr. 1991. Oceanography: An Introduction to The Marine Environment. Wm.C. Brown Publisher. Lowa. USA. 516 p.

Dewi, T. \& D. Yudi. 2008. Partikel mikroskopis dasar laut Nusantara. 
Pusat Penelitian dan Pengembangan Geologi Kelautan. Bandung. 96 hlm.

Dewi, I.S., A.A. Budiarsa, \& I.R. Ritonga. 2015. Distribusi mikroplastik pada sedimen di Muara Badak, Kabupaten Kutai Kartanegara. Depik, 4(3): 121131. https://doi.org/10.13170/depik.4.3.28 88

Dyer, K.R. 1986. Coastal and estuarine sediment dynamics. Geologi J., 22(2): 169-171 https://doi.org/10.1002/gj.335022021 0

Folk, R.L. \& J.E. Sanders. 1978. Principles of sedimentology. John Willey and Sons. New York.792 p. https://doi.org/10.1002/esp.32900403 17

Folk, R.L. \& W.C. Ward. 1957. Brazos River bar: a study in the significance of grain size parameters. $J$. of Sedimentary Research, 27(1): 3-26. https://doi.org/10.1306/74d706462b21-11d7-8648000102c1865d

Friedman, G.M. 1979. Differences in size distrobutions of populatioms of particles among sands of various origins. Sedimentology, 26(6): 859862. https://doi.org/10.1111/j.13653091.1979.tb00979.x

Ganesh, B., A.G.S.S Naidu, M. Jagannadha Rao, T. Karuna Karudu, \& P. Avatharam. 2013. Studies on textural characteristics of sediments from Gosthani River Estuary Bheemunipatnam, A.P., East Coast of India. J. Ind. Geophys. Union, 17(2): 139-151.

Gemilang, W.A.U.J., G.A. Wisha, R. Rahmawan, \& Dhiauddin. 2018. Karakteristik sebaran sedimen Pantai Utara Jawa Studi Kasus: Kecamatan Brebes Jawa Tengah. J. Kelautan Nasional, 13(2): 65-74. http://doi.org/10.15578/jkn.v1i2.6456
Ghani, A., N.A.A. Othman, \& M.K.H. Baharudin. 2012. Study on Characteristic of Sediment and Sedimentation Rate at Sungai Lembing, Kuantan, Pahang, Precedia Engineering of Malaysian Technical Universities Conference on Engineering \& Technology 2012, MUCET 2012 Part 3 - Civil and Chemical Engineering. Procedia Engineering, 53: 81-92. https://doi.org/10.1016/j.proeng.2013. 02.013

Hambali, R. \& Y. Apriyanti. 2016. Studi karakteristik sedimen dan laju sedimentasi Sungai Daeng Kabupaten Bangka Barat. J. Fropil, 4(2): 65-174.

Haryono, M.G., Mulyanto, \& Y. Kilawati. 2017. Kandungan logam berat $\mathrm{Pb}$ air laut, sedimen dan daging kerang hijau (Perva viridis). J. Ilmu dan Teknologi Kelautan Tropis, 9(1): 1-7. https://doi.org/10.29244/jitkt.v9i1.17 864

Hoekstra, P., H. Lindeboom, R. Bak, G.V.D. Bergh, D.A. Tiwi, W. Douven, J. Heun, T. Hobma, T. Hoitink, W. Kiswara, E. Meesters, Y. Noor, N. Sukmantalya, S. Nuraini, \& T.V. Weering. 2002. Teluk Banten Research Programme: an integrated coastal zone management Study. Staple (Ed.) Scientific programme Indonesia-Netherlands Proceedings of a workshop held on February $12^{\text {th }}$ 2002. Bandung. Indonesia. 59-70 p.

Ingmanson, D.E. \& W.J. Wallace. 1989. Oceanography an Introduction. Fourth Edition. Wadsworth Publishing Company. Belmont, California. 541 p.

McLaren, P. \& D. Bowles. 1985. The effects of sediment transport on grain-size distributions. J. of Sedimentary Petrology, 55(4): 457-470. https://doi.org/10.1306/212F86FC2B24-11D7-8648000102C1865D 
Nasir, M. 1983. Metode Penelitian. Ghalia Indonesia: Jakarta. 149 p.

Ningsih, E.N., F. Supriyadi, \& S. Nurdawati. 2013. Pengukuran dan analisis nilai hambur balik akustik untuk klasifikasi dasar perairan danhubungannya dengan makrozoobentos di Delta Mahakam. $J$. Penelitian Perikanan Indonesia, 19(3): 139-146. http://doi.org/10.15578/jppi.19.3.201 3.139-146

Nugroho, S.H. \& A. Basit. 2014. Sebaran sedimen berdasarkan analisis ukuran butir di Teluk Weda, Maluku Utara. J. Ilmu dan Teknologi Kelautan Tropis, 6(1): 229-240. https://doi.org/10.29244/jitkt.v6i1.86 44

Opreanu, G.O. \& F. Păun. 2007. The dynamic significance of the grain size of sediments transported and deposited by the Danube Gicu. GeoEco-Marina, 13: 111-119. https://doi.org/10.5281/zenodo.57352

Passega, R. 1964. Grain size representation by CM pattern as a geological tool. $J$. of Sedimentary Petrology, 34: 830847. https://doi.org/10.1306/74D711A42B21-11D7-8648000102C1865D

Ponce, V.M. 1989. Engineering Hydrology: Principle and Practice. Prentice-Hall Inc. New Jersey. 14 p.

Purnawan, S., I. Setiawan, \& Marwantim. 2012. Studi sebaran sedimen berdasarkan ukuran butir di perairan Kuala Gigieng, Kabupaten Aceh Besar, Provinsi Aceh. Depik, 1(1): 31-36. https://doi.org/10.13170/depik.1.1.24

Rainey, M.P., A.N. Tyler, D.J. Gilver, R.G. Bryant, \& P. McDonald. 2003. Mapping intertidal estuarine sediment grain size distributions through airborne remote sensing. Remote Sensing of Environment, 86: 480-490.
https://doi.org/10.1016/S00344257(03)00126-3

Rifardi. 2012. Ekologi Laut Modern. UR Press. Riau. 182 p.

Shepard, F.P. 1954. Nomenclature based on sand-silt-clay ratios. J. of Sedimentary Research. 24(3): 151158. https://doi.org/10.1306/d42697742b26-11d7-8648000102c1865d

Siregar, S.N., L.P. Sari, N.P. Purba, W.S. Pranowo, \& M.L. Syamsuddin. 2017. Pertukaran massa air di Laut Jawa terhadap periodisitas monsun dan Arlindo pada tahun 2015. Depik, 6(1): 44-59. https://doi.org/10.13170/depik.6.1.55 23

Solahuddin, T., E. Triarso, \& R.A. Troa. 2006. Karaktersistik tekstur sedimen berdasarkan analisis granulometri dan morfologi batupasir sepanjang Sungai Progo di Daerah Kalibawang-Pantai Trisik. D.I.Y. Proceddings of International Conference on Earth Science and Technology, 9: 6-7. https://www.onesearch.id/Record/IOS 2744.95178/Details

Stewart, H.B. 1958. Sedimentary reflection on depositional environment, in San Mignellagoon, Baju California, Mexico. AAPG Bull, 42: 2567-2618. https://doi.org/10.1306/0BDA5BFA16BD-11D7-8645000102C1865D

Wenno, L.F. \& Y. Witasari. 2001. Distribusi ukuran butir pasir di Pantai Parangtritis. Pesisir dan Pantai Indonesia. Yogyakarta. 6: 95-103.

Wibowo, S.P.A. 2011. Pengukuran besar butir sedimen laboratorium geologi laut. Pusat Penelitian Oseanografi Lembaga Ilmu Pengetahuan Indonesia. Jakarta. 55 p.

Winter, C. 2007. On the evaluation of sediment transport models in tidal environments. Sedimentary Geology, 202: 562-571. 
https://doi.org/10.1016/j.sedgeo.2007. 03.019
Research (IJSR), 6(11): 1748-1751. https://www.ijsr.net/get_abstract.php? paper_id=ART20163165

Yasin, A.M., E. Sukiyah, \& V. Isnaniawardhani. 2016. Grain Size Analysis of Quarternary Sediment from Kendari Basin, Indonesia

Received

: 22 January 2020

International J. of Science and Accepted

: 06 February 2020

: 05 April 2020 